\title{
Antioxidant mechanisms of iso-6-cassine in suppressing seizures induced by pilocarpine
}

\section{Rivelilson Mendes de Freitas, ${ }^{*}, 1$ Fábio de Oliveira Silva, ${ }^{2}$ Maria Goretti de Vasconcelos Silva, ${ }^{2}$ Dejiang Feng ${ }^{3}$}

${ }^{1}$ Laboratório de Pesquisa em Neuroquímica Experimental, Universidade Federal do Piauí, Curso de Farmácia, Brazil,

${ }^{2}$ Departamento de Química Orgânica e Inorgânica da Universidade Federal do Ceará, Brazil,

${ }^{3}$ Department of Molecular, Cellular and Developmental Biology, University of Colorado at Boulder, USA.

\begin{abstract}
The aim of this study was to evaluate the in vitro antioxidant effects of 12-[(2R,5R,6R)-5-hydroxy-6-methylpiperidin-2-yl]dodecan-2-one (iso-6cassine; ISO) and the anticonvulsant effects of ISO on pilocarpine-induced seizures in rats. Wistar rats were treated with $0.9 \%$ saline (i.p., control group), pilocarpine $(400 \mathrm{mg} / \mathrm{kg}$, i.p., pilocarpine group), and the association of ISO (1.0 $\mathrm{mg} / \mathrm{kg}$, i.p.) plus pilocarpine $(400 \mathrm{mg} / \mathrm{kg}, i . p),. 30 \mathrm{~min}$ after administration of ISO (ISO plus pilocarpine group). After the treatments all groups were observed for $1 \mathrm{~h}$. The antioxidant effect of ISO on the pilocarpine model was assessed by determining the activity of glutathione peroxidase (GPx), glutathione-Stransferase (GST) and catalase (CAT) as well as the levels of reactive species (RS) and lipid peroxidation (LP). In vitro, ISO $(5 \mu \mathrm{M})$ reduced RS and LP. ISO $(1.0 \mathrm{mg} / \mathrm{kg})$ and abolished seizures and death induced by pilocarpine in rats. ISO protected against the increase in the RS and LP levels, GST activity as well as the inhibition of GPx activity caused by pilocarpine. In addition, ISO increased the catalase activity in hippocampus of seized rats. In conclusion, the dta suggest that ISO can present anticonvulsant and antioxidant properties in the pilocarpine model of seizures in rats.
\end{abstract}

Revista Brasileira de Farmacognosia Brazilian Journal of Pharmacognosy 21(3): 437-443, May./Jun. 2011

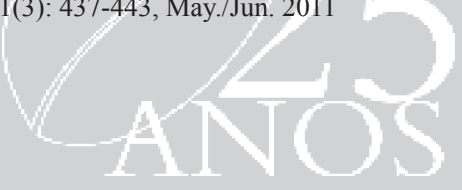

\section{Article}

Received 11 Feb 2010

Accepted 2 Nov 2010 Available online 25 Mar 2011

ISSN 0102-695X

doi: $10.1590 / \mathrm{S} 0102-695 \mathrm{X} 2011005000043$

\section{Introduction}

Iso-6-cassine (ISO) (1), piperidine alkaloid, is a heterocyclic organic not aromatic compound found in many plant species. It was isolated for the first time from Cassia sp., specie previously known as Senna spectabilis (Schrad) var. excelsa, hence the term cassine (Christofidis et al., 1977). Piperidine alkaloids derivatives with central nervous system effects include: iso-6-spectaline, which exerts neuroprotective effects against depression model, provavely associated with the inhibition of MAOA and MAOB (Christofidis et al., 1977).

Studies have shown that extract of Cassia sp. is also able to inhibit lipid peroxidation of bovine brain phospholipids, indicating its antioxidant activity (Sunil \& Muller, 1998). In accordance with the present state of scientific knowledge, the excessive production of free radicals in the organism, and the imbalance between the concentrations of these and the antioxidant defenses may be related to the pathogenesis of neurodegenerative diseases (Simonié et al., 2000; Freitas et al., 2005).

Generalized epilepsy is a chronic disorder characterized by recurrent seizures which can increase the content of reactive oxygen species (ROS) in the brain (Sudha et al., 2001). Brain is susceptible to free radical damage, considering the large lipid content of myelin sheaths and the high rate of brain oxidative metabolism (Choi, 1993). In order to protect itself from the oxidative damage, the organism has developed a complex antioxidant defense system, which is a composite to free radical scavenger molecules as vitamins or antioxidant enzymes as superoxide dismutase, catalase (CAT) or glutathione peroxidase (GPx) (Freitas, 2009). However, the brain is poor in antioxidant molecules and enzymes because it is protected by the blood-brain barrier which limits the movement of the antioxidants (Halliwell \& Gutteridge, 2007).

Exogenous antioxidants such as lipoic acid, vitamins $\mathrm{E}$ and $\mathrm{C}$ can inhibit the neuronal damage produced by lipid peroxidation (LP) during seizures. Lipoic acid, alpha-tocopherol and ascorbic acid exerted antioxidant and neuroprotective effects in seizures induced by pilocarpine (Freitas, 2009; Barros et al., 2007; Santos et al., 2008). A variety of antioxidant compounds of medicinal plants have been investigated 
due to their interesting biological properties.

Based on the pharmacological properties of antioxidant compounds, the aim of this study was to evaluate the in vitro antioxidant effect of (ISO). Considering the result obtained in vitro, the second object of this study was to investigate the anticonvulsant effect of ISO on pilocarpine induced seizures and mortality in rats. In addition, the antioxidant effect of ISO on oxidative stress induced by pilocarpine was investigated in rat hippocampus.

\section{Material and Methods}

\section{Plant material and chemistry study}

The plant was collected in September 2003, at Boa Viagem, State of Ceará, Brazil, and was identified by Prof. AG Fernandes, in the Department of Biology of the Federal University of Ceará. The voucher specimen is deposited at the Prisco Bezerra Herbarium under the voucher number 33013.

The botanical material, leaves $(1.5 \mathrm{~kg})$, stem $(5.1 \mathrm{~kg})$ and roots $(3.8 \mathrm{~kg})$, were triturated and exhaustingly extracted with ethanol and concentrated in rotative evaporator, producing 39, 27.5 and $42 \mathrm{~g}$ respectively. The leaf extract ( $39 \mathrm{~g}$ ) was then submitted to technical of selective extraction of alkaloids a fraction rich in alkaloids (FA) and a non alkaloids (FNA) one were obtained. The alkaloid fraction was submitted to chromatography on Sephadex, with methanol as movable phase. The dichloromethane fraction (7.6 g) was submitted to the same chromatography process.

The analysis of the fractions was made in chromatography in thin layer (CCD), which revealed the purity of the rich fraction in iso-6-cassine (34 $\mathrm{mg}$ ) which when subjected to the test with the reagent Dragendoff revealed an orange stain, and thus positive for alkaloids. Its spectra of ${ }^{1} \mathrm{H}$ - and ${ }^{13} \mathrm{C}$-NMR (DEPT 135, COSY, HMBC and HSQC) were obtained and compared with the data from the literature for identification. The iso-6-cassine (1) is amorphous white solid with m.p. 133.0-135.2 ${ }^{\circ} \mathrm{C}$; TLC in MeOH/EtOAc $(1: 1) \mathrm{R}_{\mathrm{f}} 0.58 ; 1 \mathrm{H} \mathrm{NMR}(\mathrm{MeOD}, 500 \mathrm{MHz}) \delta \mathrm{H} 3.83\left({ }^{1} \mathrm{H}\right.$, $\mathrm{H}-3)$; 3.06 ( $\left.{ }^{1} \mathrm{H}, \mathrm{H}-2\right)$; 3.23 (1H, H-6); 2.12 (3H, H-12'); 1.34 (3H, H-7); 1.43 (2H, H-2'); 2.47 (2H, H-10'); 1.29- 1.33 (14H, H-3' - H-9'); ${ }^{13} \mathrm{C}$ NMR (MeOD, 125 $\mathrm{MHz}) \delta \mathrm{C} 58.8(\mathrm{CH}, \mathrm{C}-2) ; 66.1(\mathrm{CH}, \mathrm{C}-3) ; 31.3\left(\mathrm{CH}_{2}\right.$, $\mathrm{C}-4) ; 23.8\left(\mathrm{CH}_{2}, \mathrm{C}-5\right) ; 57.7(\mathrm{CH}, \mathrm{C}-6) ; 16.1\left(\mathrm{CH}_{3}\right.$, C-7); $34.8\left(\mathrm{CH}_{2}, \mathrm{C}-1\right.$ ' $)$; $26.4\left(\mathrm{CH}_{2}, \mathrm{C}-2\right.$ ') $)$ 30.5-30.9 $\left(\mathrm{CH}_{2}, \mathrm{C}-3^{\prime}-8^{\prime}\right) ; 25.0\left(\mathrm{CH}_{2}, \mathrm{C}-9^{\prime}\right) ; 44.4\left(\mathrm{CH}_{2}, \mathrm{C}-10^{\prime}\right)$; $212.4\left(\mathrm{C}, \mathrm{C}-11^{\prime}\right) ; 29.9\left(\mathrm{CH}_{3}, \mathrm{C}-12^{\prime}\right)$. Data of ${ }^{13} \mathrm{C}-\mathrm{RMN}$ absorptions $(\delta)$ [(MeOD), $125 \mathrm{MHz}]$ of iso-6-cassine (12-[(2R,5R,6R)-5-hydroxy-6-methylpiperidin-2-yl] dodecan-2-one) (1) were compared with literature data. In the present work, the iso-6-cassine was suspended in
$0.5 \%$ Tween 80 distilled in water, and sonicated before use.<smiles>C[C@H]1NC(CCCCC([14CH3])=O)CC[C@H]1O</smiles>

Animals

Adult male Wistar rats $(250-280 \mathrm{~g})$ were maintained in a temperature controlled room $\left(26 \pm 1^{\circ} \mathrm{C}\right)$, with a $12 \mathrm{~h}$ light/dark cycle and food and water provided ad libitum. All experiments were performed according to the Guide for the care and use of laboratory the US Department of Health and Human Services, Washington, DC (1985). Pilocarpine was purchased from Sigma (St. Louis, MO, USA).

\section{Antioxidant effects in vitro of ISO}

In vitro experiments were carried out to evaluate the antioxidant effect of ISO. Rats were euthanized and the cerebral (whole brain) tissue was rapidly dissected, placed on ice and weighed. Tissues were immediately homogenized in cold $50 \mathrm{mM}$ Tris- $\mathrm{HCl}, \mathrm{pH} 7.4(1 / 5$, $\mathrm{w} / \mathrm{v})$. The homogenate was centrifuged at $2,400 \times \mathrm{g}$ for 15 min to yield a pellet, that was discarded, and a lowspeed supernatant (S1). The S1 was used to determine the effect of different concentrations of ISO on LP, reactive species (RS) levels, and thiol peroxidase/ oxidase activities.

For determination of LP levels, sodium nitroprusside (SNP) and malonate were used as inductors of LP (Dedeoglu et al., 2002). An aliquot of $100 \mu \mathrm{L}$ of $\mathrm{S} 1$ was added to the reaction mixture containing: $50 \mu \mathrm{M}$ SNP or malonate, ISO at different concentrations $(0.5-5 \mu \mathrm{M})$ and $30 \mu \mathrm{L}$ of $50 \mathrm{mM}$ Tris$\mathrm{HCl}, \mathrm{pH}$ 7.4. Afterward the mixture was pre-incubated at $37{ }^{\circ} \mathrm{C}$ for $1 \mathrm{~h}$. TBARS (thiobarbituric acid reactive species) were determined and the results reported as nmol MDA (malondialdehyde)/mg tissue. The levels of RS production in the hippocampus were determined as described by Chen et al. (2003). The values are expressed in percentage of induced sample.

The thiol peroxidase-like activity was carried out to determine the possible mechanism by which ISO displays antioxidant property. Free-SH groups were determined according to Ellman (1959). Results were reported as percentage of control sample.

Thiol oxidase activity was examined by the investigation of the pro-oxidant property of this compound. The rate of thiol oxidation was determined 
in the presence of $50 \mathrm{mM}$ Tris- $\mathrm{HCl}, \mathrm{pH} 7.5$, and ISO at different concentrations $(0.5-5 \mu \mathrm{M})$. Free-SH groups were determined according to Ellman (1959). Results were reported as percentage of control sample.

\section{Antioxidant effects in vivo of ISO}

For ex vivo experiments, a total of 72 rats were treated with either $1.0 \mathrm{mg} / \mathrm{kg}$ iso-6-cassine (ISO) (i.p.) or $0.9 \%$ saline (i.p.). $30 \mathrm{~min}$ after the treatments 36 rats from each above group were randomized to pilocarpine hybrochloride administration. Thus there are four groups of rats in this set of experiments: group 1 , ISO and pilocarpine co-administration $(\mathrm{n}=36)$; group 2, pilocarpine plus saline treatment; group 3, ISO alone administration; and group 4, saline treatment serves as control. After the treatments, the animals were recorded in $30 \mathrm{~cm} \times 30 \mathrm{~cm}$ chambers with: latency to first seizure, number of animals that died after pilocarpine administration. Previous work has shown that convulsions and deaths occurred within 1 and 24 $\mathrm{h}$ respectively post pilocarpine injection (Turski et al., 1983), so we decided to record the phenotypes of the animals for $1 \mathrm{~h}$ after pilocarpine administration. At the end of observations, the survivors were killed by decapitation and their brains were dissected on ice to remove hippocampus for determinations of glutathione peroxidase (GPx), glutathione-S-transferase (GST) and catalase (CAT) as well as the levels of reactive species (RS) and lipid peroxidation (LP). The pilocarpine administration rat group was constituted by those presented seizures, SE for over $30 \mathrm{~min}$ and nonphenotype survisors.

The drug dosages of pilocarpine $(400 \mathrm{mg} /$ $\mathrm{kg})$ and iso-6-cassine $(1.0 \mathrm{mg} / \mathrm{kg})$ were determined by previous study in our lab (Freitas, 2009), and the present study (data not shown). The drug doses used in this present study are not equivalent to those used by humans because rats have different metabolic rates.

Considering that studies have demonstrated that status epilepticus induced by pilocarpine is followed by changes in the level of oxidative stress (Freitas et al., 2005; Dal-Pizzol et al., 2000), and that ISO abolished seizures in this model, the effect of ISO on oxidative stress caused by pilocarpine was investigated. Subsequently to the seizure episode induced by pilocarpine, rats were decapitated. Animals which did not display seizure activity were considered protected and decapitated one hour after the compound administration. The $\mathrm{S} 1$ was obtained as described the steps above in section.

An aliquot of S1 $(200 \mu \mathrm{L})$ from rats belonging to the experimental groups was reacted as described above except for the pre-incubation step as described the steps above in section. To estimate the level of hippocampus RS production, S1 was diluted $(1: 10)$ in $50 \mathrm{mM}$ Tris- $\mathrm{HCl}(\mathrm{pH}$ 7.4) and incubated with $10 \mu \mathrm{L}$ of DCHF-DA $(1 \mathrm{mM})$. The RS levels were determined as described the steps above in section. The results above were expressed as mM. LP levels in all groups were measured by previously described by Draper \& Hadley (1990). The results above were expressed as nmol of malondialdehyde (MDA)/g wet tissue.

CAT activity was measured in the allgroups by the method that uses $\mathrm{H}_{2} \mathrm{O}_{2}$ to generate $\mathrm{H}_{2} \mathrm{O}$ and $\mathrm{O}_{2}$ (Chance \& Maehly, 1955). Protein concentration was measured by the method of Lowry et al. (1951) Results are expressed as $\mathrm{mmol} / \mathrm{min} / \mathrm{mg}$ of protein (Chance \& Maehly, 1955; Maehly \& Chance, 1954).

GPx activity in S1 of brain was assayed spectrophotometrically by the method of Wendel (1981), through the glutathione/NADPH/glutathione reductase system, by the dismutation of $\mathrm{H}_{2} \mathrm{O}_{2}$ at 340 $\mathrm{nm}$. The enzymatic activity was expressed in nmol $\mathrm{NADPH} / \mathrm{min} / \mathrm{mg}$ protein.

GST activity in S1 of brain was determined spectrophotometrically at $340 \mathrm{~nm}$ as described by Habig et al. (1974). The enzymatic activity was expressed as nmol CDNB conjugated $/ \mathrm{min} / \mathrm{mg}$ protein (nmol/min/mg protein).

\section{Statistical analysis}

Results of latency to first seizure and neurochemical alterations between different groups were compared using ANOVA and the StudentNewman-Keuls test as post hoc test, because these results show a parametric distribution. The numbers of animals that seizured and that survived were calculated as percentages respectively, and compared with a nonparametric test $\left(\chi^{2}\right)$. In all situations statistical significance was reached at $p$ less-than-or-equals, slant 0.05 .

\section{Results}

Anticonvulsant effects of ISO on pilocarpine-induced seizures

Pilocarpine induced the first seizure at $34.93 \pm 0.67 \mathrm{~min}$. All the animals studied showed generalized tonic-clonic convulsions with status epilepticus (SE), and 37\% survived the seizures. All animals pretreated with the ISO selected for this study were observed for $1 \mathrm{~h}$ after pilocarpine injection and its manifested alterations in behavior, such as peripheral cholinergic signs $(100 \%)$, tremors $(100 \%)$, staring spells, facial automatisms, wet dog shakes, rearing and motor seizures $(25 \%)$, which develop progressively within 1-2 $\mathrm{h}$ into a long-lasting SE (25\%). Table 1 
shows that when administered at the dose $(1.0 \mathrm{mg} / \mathrm{kg})$ before pilocarpine, ISO reduced by $75 \%$ the percentage of animals that seized $(p<0.0001)$, increased $(154 \%)$ latency to the first seizure $(196.87+2.12 \mathrm{~min})[p<0.0001]$ and increased $(53 \%)$ the survival percentage $(p<0.0001)$ as compared with the pilocarpine-treated group (Table 1). None of the animals that received injections of isotonic saline (control) or iso-6-cassine alone showed seizure activity (Table 1).

Table 1. Effect of pretreatment with iso-6-cassine (ISO) on pilocarpine-induced seizures and lethality in adult rats.

\begin{tabular}{lcccc}
\hline \multicolumn{1}{c}{ Groups } & $\begin{array}{c}\text { Latency to } \\
\text { first seizures } \\
\text { (min) }\end{array}$ & $\begin{array}{c}\text { Percentage } \\
\text { seizures }\end{array}$ & $\begin{array}{c}\text { Percentage } \\
\text { survival }\end{array}$ & $\begin{array}{c}\text { Number of } \\
\text { animals/ } \\
\text { group }\end{array}$ \\
\hline Pilocarpine & $34.93 \pm 0.67$ & 100 & 37 & 24 \\
$\begin{array}{l}\text { ISO plus } \\
\text { pilocarpine }\end{array}$ & $196.87 \pm 2.12^{\mathrm{c}}$ & $25^{\mathrm{a}}$ & $90^{\mathrm{a}}$ & 24 \\
ISO & 00 & 00 & $100^{\mathrm{a}, \mathrm{b}}$ & 24 \\
\hline
\end{tabular}

Animals were pretreated acutely, intraperitoneally, with iso-6cassine $(1.0 \mathrm{mg} / \mathrm{kg}$, ISO $)$ and $30 \mathrm{~min}$ afterwards received pilocarpine $400 \mathrm{mg} / \mathrm{kg}$, i.p. Results for latency to first seizure are expressed as mean \pm S.E.M of the number of experiments shown in the table. Result for percentage seizures and percentage survival are expressed as percentages of the number of animals from each experimental group. ${ }^{a} p<0.0001$ as compared with pilocarpine group $\left(\chi^{2}\right.$-test). ${ }^{b} p<0.0001$ as compared with ISO plus pilocarpine group ( $\chi^{2}$-test).

Antioxidant effects in vitro of ISO on pilocarpineinduced seizures

ISO at concentrations greater than $5 \mu \mathrm{M}$ reduced LP induced by malonate (Table 2). The IC50 and Imax values of ISO for LP induced by malonate were $0.9 \mu \mathrm{M}$ and $69 \%$. The IC50 and Imax values of ISO for LP induced by SNP were $4.5 \mu \mathrm{M}$ and $44 \%$. As shown in Table 1, ISO at concentrations greater than 5 $\mu \mathrm{M}$ reduced LP induced by SNP. As can be observed in Table 1, ISO (0.5-5 $\mu \mathrm{M})$ reduced RS production induced by sodium azide in hippocampus homogenates. The calculated IC50 value for this compound was 1.0 $\mu \mathrm{M}$ and Imax was $51 \%$. ISO $(0.5-5 \mu \mathrm{M})$ did not display thiol peroxidase-like activity, as well as did not present thiol oxidase activity (data not shown).

\section{Antioxidant effects in vivo of ISO on pilocarpine- induced seizures}

Post hoc comparisons showed that pilocarpine significantly increased LP levels in rat hippocampus when compared to the control group $[p<0.0001]$. Pretreatment with ISO at dose of $1.0 \mathrm{mg} / \mathrm{kg}$ protected against the increase of LP levels caused by pilocarpine in rat hippocampus (Table 3).

Post hoc comparisons showed that pilocarpine significantly increased RS levels in rat hippocampus when compared to the control group $[p<0.0001]$. Pretreatment with ISO at the dose of $1.0 \mathrm{mg} / \mathrm{kg}$ protected against the increase of RS levels caused by pilocarpine in rat hippocampus. ISO alone did not alter LP and RS levels when compared to the control group (Table 3).

Post hoc comparisons revealed that pilocarpine no altered CAT activity $[p<0.0001]$. The increase of CAT activity induced by ISO $(1.0 \mathrm{mg} / \mathrm{kg}, i . p$. $)$ was observed in rat hippocampus treated with pilocarpine when compared to the control group (Table 3 ) $[p<0.0001]$. CAT activity remained increased in rats which received ISO at the dose of $1.0 \mathrm{mg} / \mathrm{kg}$ when compared to the pilocarpine group alone (Table 3 ).

Post hoc comparisons showed that pilocarpine significantly decreased GPx activity in rat hippocampus when compared to the control group $[p<0.0001]$. The decrease of GPx activity induced by pilocarpine was reversed in rat hippocampus treated with ISO when compared to the pilocarpine group [ $p<0.0001]$. Post hoc comparisons revealed that pilocarpine increased GST activity $[p<0.0001]$. Pretreatment with ISO protected against the increase in GST activity caused by pilocarpine in rat hippocampus [ $p<0.0001]$. ISO alone did not alter CAT, GPx and GST activities, when compared to the control group (Table 3 ).

Table 2. Effect of pretreatment with ISO on RS and LP levels induced by SNP and malonate in rat hippocampus in vitro.

\begin{tabular}{cccc}
\hline Groups & $\begin{array}{c}\text { LP-malonate } \\
\text { (nmol of MDA/ } \\
\text { mg tissue) }\end{array}$ & $\begin{array}{c}\text { LP-SNP } \\
\text { (nmol of MDA/ } \\
\text { mg tissue) }\end{array}$ & $\begin{array}{c}\text { RS } \\
\text { (\% of induced) }\end{array}$ \\
\hline Control & $144.25 \pm 1.54(7)$ & $124.89 \pm 1.24(7)$ & $44.57 \pm 1.84(7)$ \\
Induced & $285.76 \pm 2.84(6)^{\mathrm{a}}$ & $274.43 \pm 2.25(6)^{\mathrm{a}}$ & $94.94 \pm 2.84(6)^{\mathrm{a}}$ \\
ISO 0.5 & $265.14 \pm 1.75(6)$ & $267.98 \pm 1.46(6)$ & $90.89 \pm 1.23(6)$ \\
ISO 1.0 & $85.89 \pm 1.32(6)^{\mathrm{a}, \mathrm{b}}$ & $109.67 \pm 1.63(6)^{\mathrm{a}, \mathrm{b}}$ & $36.84 \pm 1.53(6)^{\mathrm{a}, \mathrm{b}}$ \\
ISO 5.0 & $142.98 \pm 1.54(6)^{\mathrm{b}}$ & $122.93 \pm 1.52(6)^{\mathrm{b}}$ & $46.21 \pm 1.85(6)^{\mathrm{b}}$ \\
\hline
\end{tabular}

Results are mean \pm S.E.M for the number of animals shown inside in parentheses. The differences in experimental groups were determined by analysis of variance. ${ }^{a} p<0.05$ as compared to control animals (t-Student-Neuman-Keuls test); ${ }^{b} p<0.05$ as compared to induced group (t-Student-Neuman-Keuls test); ${ }^{c} p<0.0001$ as compared with pilocarpine group (ANOVA and Student-Newman-Keuls test). Abbreviations: ISO 0.5: $0.5 \mathrm{mg} / \mathrm{kg}$; ISO 1.0 : ISO $1.0 \mathrm{mg} / \mathrm{kg}$; ISO 5.0: ISO $5 \mathrm{mg} / \mathrm{kg}$.

\section{Discussion}

The present study demonstrates that ISO had antioxidant activity in vitro and anticonvulsant action in the pilocarpine model in rats. ISO protected the brain against biochemical alterations caused by pilocarpine, suggesting that its antioxidant activity is involved, at least in part, in the anticonvulsant action. 
Table 3. Effect of pretreatment with ISO on oxidative stress in pilocarpine-induced seizures.

\begin{tabular}{lccccc}
\hline Groups & \multirow{2}{*}{$\mathrm{RS}(\mathrm{mM})$} & $\begin{array}{c}\mathrm{LP}(\mathrm{nmol} \text { of MDA/ } \\
\text { mg protein) }\end{array}$ & $\begin{array}{c}\text { CAT (mmol/min// } \\
\text { mg of protein) }\end{array}$ & $\begin{array}{c}\text { GPx (nmol NADPH/ } \\
\text { min/mg protein) }\end{array}$ & $\begin{array}{c}\text { GST (nmol/min/mg } \\
\text { protein) }\end{array}$ \\
\hline Control & $80.55 \pm 1.12(7)$ & $1.12 \pm 0.12(7)$ & $14.99 \pm 0.62(7)$ & $24.40 \pm 1.90(7)$ & $140.63 \pm 1.72(7)$ \\
Pilocarpine & $155.89 \pm 0.67(6)^{\mathrm{a}}$ & $2.12 \pm 0.05(6)^{\mathrm{a}}$ & $15.19 \pm 1.07(6)^{\mathrm{a}}$ & $20.92 \pm 1.87(6)^{\mathrm{a}}$ & $167.96 \pm 1.63(6)^{\mathrm{a}}$ \\
ISO plus pilocarpine & $79.92 \pm 0.53(6)^{\mathrm{b}}$ & $1.09 \pm 0.04(6)^{\mathrm{b}}$ & $13.89 \pm 0.64(6)^{\mathrm{b}}$ & $25.18 \pm 1.67(6)^{\mathrm{b}}$ & $145.21 \pm 1.52(6)^{\mathrm{b}}$ \\
ISO & $81.14 \pm 1.02(6)$ & $1.14 \pm 0.02(6)$ & $14.14 \pm 1.24(6)$ & $23.92 \pm 2.12(6)$ & $139.98 \pm 1.12(6)$ \\
\hline
\end{tabular}

Results are mean \pm S.E.M for the number of animals shown inside in parentheses. The differences in experimental groups were determined by analysis of variance. ${ }^{a} p<0.05$ as compared to control animals (t-Student-Neuman-Keuls test); ${ }^{b} p<0.05$ as compared to pilocarpine group (t-Student-NeumanKeuls test).

This conclusion derives from the following results; ISO reduced LP induced by SNP and malonate as well as the RS formation induced by azide in vitro. The administration of ISO in rats: abolished seizures and death induced by pilocarpine; protected against the increase of RS and LP levels as well as GST activity induced by pilocarpine; protected against the decrease of GPx activity and increased the latency to the onset of seizures induced by pilocarpine in rats. A closer inspection of the in vitro results revealed that ISO, at low concentrations, was able to prevent LP induced by malonate or SNP in rat hippocampus.

Accordingly, it has been reported that antioxidants compounds have anticonvulsant effects (Wilhelm et al., 2009; Xavier et al., 2007). The IC50 values of ISO for LP induced by malonate or SNP were 0.9 and $4.5 \mu \mathrm{M}$, respectively. Therefore, we assume that the antioxidant effect of ISO was not dependent on the chemical (malonate or SNP) used for the LP induction. Furthermore, the effect of ISO demonstrated in the RS assay supports the antioxidant activity of this antioxidant compound. Although the glutathione peroxidase-like activity has been reported as the major mechanism by which antioxidant compounds exert anticonvulsant activity (Costello \& Delanty, 2004), the antioxidant effect of ISO in rat hippocampus brain homogenates might be explained by the glutathione peroxidase-like activity. Thus, more studies are needed to elucidate the mechanisms involved in ISO anticonvulsant activity.

Several reports have demonstrated that antioxidant compounds displayed an anticonvulsant effect in different animal models (Wilhelm et al., 2009; Oliveira et al., 2005). In this study, ISO revealed an anticonvulsant effect on the pilocarpine model in rats. In fact, ISO at the dose of $1.0 \mathrm{mg} / \mathrm{kg}$ abolished seizures and death induced by pilocarpine. A preclinical study demonstrated the importance of antioxidant deficiency in vivo to substantial increase in the susceptibility to pilocarpine-induced seizures in rats (Freitas et al., 2005; Oliveira et al., 2007). This study showed that rats were more susceptible to pilocarpine-induced excitotoxicity, which resulted in a higher seizure rate when compared with the controls on an antioxidant adequate treatment.
In epilepsy models, the application of antioxidant compounds normalized the electroencephalographic pattern and reduced the tissue damage assessed by histological methods (Milhaud et al., 2003; Rubin \& Willmore, 1980). Santos and coworkers (2008) showed that in pilocarpine-induced seizures the breakdown of the blood-brain barrier is attenuated by vitamin $\mathrm{C}$ administration.

There are points of evidence suggesting that oxidative stress is important in hippocampus tissue damage following seizure induction (Freitas et al., 2005; Liang et al., 2007). The brain is a preferential target for the peroxidative process because it has a high content of polyunsaturated fatty acids (Gutteridge \& Halliwell, 1994). In fact, in this study LP was evidenced by an increase in the levels of RS and TBARS in rats that received pilocarpine, which were reduced by ISO. An increase in these parameters is associated to the accumulation of highly reactive free radicals. Thus, ISO anticonvulsant effect could be explained, at least in part, by its antioxidant activity. It is important to point out that the protective effect of ISO against alterations caused by pilocarpine administration was evidenced at low doses. Seizures followed by a substantial increase of LP in brain tissue might be diminished by substances with antioxidant properties (Ferreira et al., 2009).

Besides, GST, known as phase II enzymes, is widely distributed, catalyzing and binding proteins which promotes the conjugation of GSH with a variety of reactive electrophilic compounds resulting in the formation of substances which are easily excreted from the body (Cervello et al., 1992). In this report, it was verified an increase of GST activity in the animals that received pilocarpine administration. We believed that the stimulation of GST activity may be associated with an increase of RS levels. Gutteridge \& Halliwell (1994) reported that under an oxidative stress the GST activity is increased in order to cope with the increase in the production of RS and LP. Like this, it has been reported that GST is an antioxidant defense and serves to protect the tissues against oxidative stress. Additionally, ISO at the dose of $100 \mathrm{mg} / \mathrm{kg}$ was effective in protecting this alteration in the GST activity. 
Simonié and coworkers (2000) showed that the conversion of $\mathrm{H}_{2} \mathrm{O}_{2}$ to $\mathrm{H}_{2} \mathrm{O}$ can be made by CAT and GPx activity. An elevation in ROS formation can be accompanied by an immediate compensatory mechanism of these enzymes. In this study, there was no observed alteration in CAT activity. However, a decrease of GPx activity in the pilocarpine group was verified. The seizures activate the ROS scavenging enzymes, such as CAT, indicating a cellular response to the increased ROS formation (Andersson et al., 1993; Maxwell et al., 1999). However, the ISO administration was effective in protecting against the alteration in GPx activity. Based on this result we suppose that GPx is probably involved in defending against cell oxidation induced by pilocarpine in rat hippocampus. In addition, CAT and GPx are probably involved in defending against oxidative induced by pilocarpine in rat hippocampus pretreated with iso-6-cassine. The data suggests that neuroprotective effect of this compound is involved in the regulation of these enzymes. This result is in accordance to other study of our research group that demonstrated the lack of effect of an antioxidant compounds in the regulation of antioxidant enzymatic activity (Freitas et al., 2005; Xavier et al., 2007; Ferreira et al., 2009).

\section{Conclusion}

In summary, the most relevant additional findings of the present study are that ISO exert antioxidant effect in vitro. Iso-6-cassine had anticonvulsant action in the pilocarpine model in rats, since it was effective in increasing the latency to the onset of seizure induced by pilocarpine in rats. Finally, iso-6-cassine protected the brain against oxidative stress caused by pilocarpine in rat hippocampus. The anticonvulsant effect of ISO in pilocarpine-induced seizures could be attributed, at least in part, to its antioxidant activity.

\section{Acknowledgements}

This work was supported in part by grants from CNPq, Brazil. RMF is fellow from CNPq.

\section{References}

Andersson CM, Hallberg A, Brattsand R, Cotgreave IA, Engman L, Persson J 1993. Glutathione peroxidase like activity of diaryl tellurides. Bioorg Med Chem Lett 3: 2553-2558.

Barros DO, Xavier SM, Barbosa CO, Silva RF, Maia FD, Oliveira AA, Freitas RM 2007. Effects of the vitamin $\mathrm{E}$ in catalase activities in hippocampus after status epilepticus induced by pilocarpine in Wistar rats. Neurosci Lett 416: 227-230.
Cervello I, Lafuente A, Giralt M, Mallol J 1992. Enhanced glutathione S-transferase (GST)activity in pregnant rats treated with benzo(a)pyrene. Placenta 13: 273280.

Chance B, Maehly AC 1955. Assay of catalases and peroxidases. Methods Enzymol 2: 764-768.

Chen Q, Vazquez EJ, Moghaddas S, Hoppel CL, Lesnefsky EJ 2003. Production of reactive oxygen species by mitochondria: central role of complex III. J Biol Chem 278: 36027-36031.

Choi BH 1993. Oxygen, antioxidants and brain disfunction. Yonsei Med J 34: 1-10.

Costello DJ, Delanty N. 2004. Oxidative injury in epilepsy: potential for antioxidant therapy? Exp Rev Neurotherap 4: 541-553.

Dal-Pizzol F, Klamt F, Vianna MMR, Schorer N, Quevedo J, Benfato MS, Moreira JCF, Walz R 2000. Lipid peroxidation in hippocampus early and late after status epilepticus induced by pilocarpine of kainic acid in Wistar rats. Neurosci Lett 291: 179-182.

Dedeoglu A, Ferrante RJ, Andreassen OA, Dillmann WH, Beal MF 2002. Mice overexpressing $70-\mathrm{kDa}$ heat shock protein showincreased resistance to malonate and 3-nitropropionic acid. Exp Neurol 176: 262-265.

Draper HH, Hadley M 1990. Malondialdehyde determination as an index of lipid peroxidation. Methods Enzymol 186: 421-431.

Ellman GL 1959. Tissue sulfhydryl groups. Arch Biochem Biophys 82: 70-77.

Ferreira PMP, Militão GCG, Freitas RM 2009. Lipoic acid effects on lipid peroxidation level, superoxide dismutase activity and monoamines concentration in rat hippocampus. Neurosci Lett 464: 131-134.

Freitas RM, Souza FCF, Vasconcelos SMM, Viana GSB, Fonteles MMF 2005. Oxidative stress in the hippocampus after status epilepticus in rats. FEBS $J$ 272: 1307-1312.

Freitas RM 2009. The evaluation of effects of lipoic acid on the lipid peroxidation, nitrite formation and antioxidant enzymes in the hippocampus of rats after pilocarpineinduced seizures. Neurosci Lett 455: 140-144.

Gutteridge JMC, Halliwell B 1994. Antioxidants: elixirs of life or media hype? Antioxidants in Nutrition, Health and Disease, Oxford University Press.

Habig WH, Pabst MJ, Jakoby WB 1974. Glutathione S-transferases: The first enzymatic step in mercapturic acid formation. $J$ Biol Chem 249: 7130-7139.

Halliwell B, Gutteridge JMC 2007. Free radicals in biology and medicine. $4^{\text {th }}$ ed. Oxford: Clarendon Press, Oxford Science publications.

Christofidis I, Welter A, Jadot J 1977. Spectaline and iso-6 cassine, two new piperidin 3-ol alkaloids from the leaves of Cassia spectabilis. Tetrahedron 33: $977-$ 999.

Liang LP, Beaudoin ME, Fritz MJ, Fulton R, Patel M 2007. 
Kainate-induced seizures, oxidative stress and neuronal loss in aging rats. Neuroscience 147: 11141118.

Lowry H, Rosebrough NJ, Farr AL, Randall RJ 1951. Protein measurements with the folin phenol reagent. $J$ Biol Chem 193: 265-275.

Maehly AC, Chance B 1954. The assay of catalases and peroxidases. Methods Biochem Anal 1: 357-359.

Maxwell DP, Wang Y, McIntosh L 1999. The alternative oxidase lowers mitochondrial reactive oxygen production in plant cells. Proc Natl Acad Sci U S A. 96: 8271-8276.

Milhaud D, Rondouin G, Lerner-Natoli M, Bockaert J, LafonCazal M 2003. Neuroprotective activity of antazoline against neuronal damage induced by limbic status epilepticus. Neuroscience 120: 475-484.

Oliveira AA, Nogueira CRA, Nascimento VS, Aguiar LMV, Freitas RM, Souza FCF, Vasconcelos SMM, Viana GSB, Fonteles MMF 2005. Evaluation of levetiracetam effects on pilocarpine-induced seizures: Cholinergic muscarinic system involvement. Neurosci Lett 385: 184-188.

Oliveira AA, Almeida JPC, Freitas RM, Nascimento VS, Aguiar LMV, Júnior HVN, Fonseca FN, Viana GSB, Souza FCF, Fonteles MMF 2007. Effects of levetiracetam in lipid peroxidation level, nitritenitrate formation and antioxidant enzymatic activity in mice brain after pilocarpine-induced seizures. Cell Mol Neurobiol 27: 395-406.

Rubin JJ, Willmore LJ 1980. Prevention of iron-induced epileptiform discharges in rats by treatment with antiperoxidants. Exper Neurol 67: 472-480.

Santos LF, Freitas RL, Xavier SM, Saldanh GB, Freitas RM 2008. Neuroprotective actions of vitamin $C$ related to decreased lipid peroxidation and increased catalase activity in adult rats after pilocarpine-induced seizures. Pharmacol Biochem Beh 89: 1-5.
Simonié A, Laginja J, Varljen J, Zupan G, Erakovié V 2000. Lithium plus pilocarpine induced status epilepticusbiochemical changes. Neurosci Res 36: 157-166.

Sudha K, Rao AV, Rao A 2001. Oxidative stress and antioxidants in epilepsy. Clin Chim Acta 303: 19-24.

Sunil KKC, Müller K 1998. Inhibition of leukotriene biosynthesis and lipid peroxidation in biological models by the extract of Cassia fistula. Phytoter Res 12: 465-531.

Turski WA, Cavalheiro EA, Schwartz M, Czuczwar SJ, Kleinrok Z, Turski L 1983. Limbic seizures produced by pilocarpine in rats: a behavioural, electroencephalographic and neuropathological study. Behav Brain Res 9: 315-335.

Wendel A 1981. Glutathione peroxidase. Meth Enzymol 77: 325-333.

Wilhelm EA, Jesse CR, Bortolatto CF, Nogueira CW, Savegnago L 2009. Anticonvulsant and antioxidant effects of 3-alkynyl selenophene in 21-day-old rats on pilocarpine model of seizures. Brain Res Bull 79: 281-287.

Xavier SML, Barbosa CO, Barros DO, Silva RF, Oliveira AA, Freitas RM 2007. Vitamin C antioxidant in hippocampus of adult Wistar rats after seizures and status epilepticus induced by pilocarpine. Neurosci Lett 420: 76-79.

\section{*Correspondence}

Rivelilson Mendes de Freitas

Laboratório de Pesquisa em Neuroquímica Experimental, Curso de Farmácia, Universidade Federal do Piauí

Campus Universitário Ministro Petrônio Portella, Bairro Ininga, 64049-550 Teresina-PI, Brazil

rivelilson@pq.cnpq.br

Tel./Fax: +55 86-3215-5870 